\title{
電池の小型化と軽量 化*
}

\author{
杉本幸 一**
}

\section{1. は じめに}

一般に物質の物理的あるいは化学的変化を利用し, こ れらの変化に際して放出するエネルギを直接電気エネル ギに変換する装置を電池とよんでいる. 電池が構成され るなめには, (1) 電池反応の進行に伴って系の遊離エネル ギが減少する，(2)電池反応を進行させる場合，電子の授 受は適当な装置を工夫し電池外の導線を通って行われ， 電池内で行われないの 2 条件が必要である. しかし,こ れらの条件のみでは実用電池にならない，実用電池は起 電力が高く, 放電時の電圧降下とその経時变化が少なく, 単位重量あるいは体積あたりの容量が大きく，取扱いに 便利で保存性, 耐久性潐れ，さらにその上安価でなく てはならない1)。これらをすべて満足させる電池を製造 することは困難であり，用途に応じて電池性能と価格の いずれかを犠牲にしているのが現状である。

我が国に打いて昭和 51 年に 1 次電池は約 17.6 億個生 産されたが, その内約 $95 \%$ がマンガン乾電池で占められ ている2). しかしながら，酸化銀電池などの小型高性能 電池の伸びが著しく, 関心を集めて いる. 小型電池の使用される分野と しては電子腕時計, カメラ, 電卓等 の小型携帯機器である.これらの機 器の発展を支壳ているものはICを 始めとするエレクトロニクス技術に 負らところが大であるが，電源に小 型で優れた特性を有する電池が開発 されたことも見逃せない。

\section{2. 小型化，軽量化の現状}

電池汶対する小型化の要請が最も 強いのは電子腕時計あるいは電卓と いった分野ではなかららか。これら 機器の携帯性を高めデザインに多様 性を持たす上で電池の占める比重は 極めて高い，例を水晶腕時計にとれ ば平面積の 20〜30\%を電池が占め

* 原稿受付 昭和 52 年 9 月 20 日.

** (株)第二精工舎 (東京都 江東区龟 戸 6-31-1)
ており, 小型化あるいは薄型化によるメリットは非常に 大きい，また，消費電流も IC，モー夕等の進歩により低 減化されて打り, 小さな容量の電池でも十分実用化でき るレベルに到達して㧍り, より小型の電池が要求されて いる.

小型化されても実用化されるには一定の電気容量が必 要であり,エネルギ密度の高い電池でなければならない， 一方, 軽量化の観点からみると小型電池として実用化さ れているものは電池特性も優れており, 所定のエネルギ を得るにるより小型の電池ですむため, 結果として軽量 化が達成されるといらヶースが多いのではなかららか。

電池容量及び電圧は陰陽極活物質の選択に上り決定さ れるが，電池汇通常用いられている活物質の体積あたり あるいは重量あたりの電気容量と起電力を表 1 亿示す.

電池を構成するためには陰陽極活物質のほかに年（ケ 一ス)，ガスケット，七パレータ，電解液等が必要であ り, 小型化，軽量化のためにはこれらの材料についても 十分な配慮が必要である.

表 1 電池活物質の容量と起電力

\begin{tabular}{|c|c|c|c|c|c|c|}
\hline \multirow{2}{*}{\multicolumn{2}{|c|}{ 活 物 質 }} & \multirow{2}{*}{ 電 } & \multirow{2}{*}{ 反 } & \multicolumn{2}{|c|}{ 電気容量 } & \multirow{2}{*}{$\begin{array}{c}\text { 標準電極 } \\
\text { 電位 } \\
\left(25^{\circ} \mathrm{C}\right) \\
(\mathrm{V}) \\
\end{array}$} \\
\hline & & & & $\mathrm{Ah} / \mathrm{g}$ & $\mathrm{Ah} / \mathrm{cc}$ & \\
\hline \multirow{3}{*}{ 陰 } & $\mathrm{Li}$ & $\mathrm{Li}^{+}+\mathrm{e}^{-}=\mathrm{Li}$ & & 3.860 & 2.06 & -3.05 \\
\hline & $\mathrm{Mg}$ & $\int \mathrm{Mg}^{2+}+2 \mathrm{e}^{-}=\mathrm{Mg}$ & & 2.21 & 3.85 & -2.37 \\
\hline & & $\operatorname{lgg}(\mathrm{OH})_{2}+2 \mathrm{e}^{-}=\mathrm{N}$ & $-2 \mathrm{OH}^{-}$ & 2.21 & 3.85 & -2.69 \\
\hline \multirow{2}{*}{ 極 } & $\mathrm{Zn}$ & $Z^{2+}+e^{-}=Z n$ & & 0.82 & 5.85 & -0.763 \\
\hline & & $\left\{\mathrm{Zn}(\mathrm{OH})_{2}+2 \mathrm{e}^{-}=\mathrm{Zr}\right.$ & $2 \mathrm{OH}^{-}$ & 0.82 & 5.85 & -1.245 \\
\hline \multirow{2}{*}{ 活 } & & $\mathrm{ZnO}_{2}{ }^{2-}+2 \mathrm{H}_{2} \mathrm{O}+2$ & $\mathrm{Zn}+4 \mathrm{OH}^{-}$ & 0.82 & 5.85 & -1.216 \\
\hline & $\mathrm{Cd}$ & $\mathrm{Cd}(\mathrm{OH})_{2}+2 \mathrm{e}^{-}=\mathrm{Co}$ & $\mathrm{OH}^{-}$ & 0.48 & 4.15 & -0.809 \\
\hline \multirow{2}{*}{ 物 } & $\mathrm{A} 1$ & $\mathrm{Al}^{3+}+3 \mathrm{e}^{-}=\mathrm{Al}$ & & 2.98 & 8.04 & -1.66 \\
\hline & $\mathrm{Fe}$ & $\mathrm{Fe}(\mathrm{OH})_{2}+2 \mathrm{e}^{-}=\mathrm{F}$ & $2 \mathrm{OH}^{-}$ & 0.96 & 7.56 & -0.877 \\
\hline \multirow{3}{*}{ 質 } & $\mathrm{Pb}$ & $\left(\mathrm{Pb}^{2+}+2 \mathrm{e}^{-}=\mathrm{Pb}\right.$ & & 0.26 & 2.95 & -0.216 \\
\hline & & $\mathrm{PbSO}_{4}+2 \mathrm{e}^{-}=\mathrm{Pb}+$ & & 0.26 & 2.95 & -0.356 \\
\hline & & $\mathrm{PbI}_{2}+2 \mathrm{e}^{-}=\mathrm{Pb}+2$ & & 26 & 2.95 & -0.365 \\
\hline \multirow[b]{2}{*}{ 陽 } & $\mathrm{MnO}_{2}$ & $\mathrm{MnO}_{2}+4 \mathrm{H}^{+}+2 \mathrm{e}^{-}$ & ${ }^{2+}+2 \mathrm{H}_{2} \mathrm{O}$ & 07 & 1.54 & 1.23 \\
\hline & $\mathrm{PbO}_{2}$ & $\left\{\mathrm{PbO}_{2}+\mathrm{SO}_{4}{ }^{2-}+4 \mathrm{HI}\right.$ & $2 \mathrm{e}^{-}=\mathrm{PbSO}_{4}+2 \mathrm{H}_{2} \mathrm{O}$ & 0.240 & 2.26 & 1.68 \\
\hline 極 & & $\mathrm{PbO}_{2}+\mathrm{H}_{2} \mathrm{O}+2 \mathrm{e}^{-}=$ & $\mathrm{O}+2 \mathrm{OH}^{-}$ & 0.240 & 2.26 & 0.25 \\
\hline \multirow[t]{2}{*}{ 活 } & $\mathrm{HgO}$ & $\mathrm{HgO}+\mathrm{H}_{2} \mathrm{O}+2 \mathrm{e}^{-}=$ & $+2 \mathrm{OH}^{-}$ & 0.248 & 2.76 & 0.10 \\
\hline & $\mathrm{CuO}$ & $2 \mathrm{CuO}+\mathrm{H}_{2} \mathrm{O}+2 \mathrm{e}^{-}=$ & ${ }_{2} \mathrm{O}+2 \mathrm{OH}^{-}$ & 0.670 & 4.32 & -0.16 \\
\hline 物 & $\mathrm{Ag}_{2} \mathrm{O}$ & $\mathrm{Ag}_{2} \mathrm{O}+\mathrm{H}_{2} \mathrm{O}+2 \mathrm{e}^{-}=$ & $\mathrm{Ag}+2 \mathrm{OH}^{-}$ & 0.232 & 1.67 & 0.34 \\
\hline \multirow[t]{2}{*}{ 質 } & $\mathrm{AgO}$ & $\mathrm{AgO}+\mathrm{H}_{2} \mathrm{O}+2 \mathrm{e}^{-}=$ & ${ }_{2} \mathrm{O}+2 \mathrm{OH}^{-}$ & 0.432 & 3.22 & 0.57 \\
\hline & $\mathrm{O}_{2}$ & $\mathrm{O}_{2}+2 \mathrm{H}_{2} \mathrm{O}+4 \mathrm{e}^{-}=$ & & 3.329 & (iiq. ) & 0.40 \\
\hline
\end{tabular}


3. 小型 1 次電池の

種類とその特性

小型電池は一般にボタン型 電池と呼ばれている形状のも のが多く，各種の電池系と寸 法があり，用途に応じて選択 が可能である，最も普及して いるのは水銀電池, 酸化銀電 池, 酸化銀(II)電池であるが, このほかマンガン電池, ニッケル亜鉛電池等があり，表 2 にボタン型電池の種類とその概要を示す.

表 3 にボタン型電池の寸法と電池系及びその電気容量 を示す．空闌は現在市販されていない寸法であるが，さ らに小型化, 薄型化された電池の出現が予想されるとこ ろである.

\section{1 放電特性}

容量の大きいこと, 電圧変動の小さいこと等が要求さ れるが電池系によりそれぞれの特色がある．電解液に菁
表 2 ポタン型電池の概要

\begin{tabular}{|c|c|c|c|c|c|c|c|c|c|}
\hline \multirow{2}{*}{ 電 } & \multicolumn{2}{|c|}{ 電 } & 池 & 構 & 成 & & \multirow{2}{*}{$\begin{array}{l}\text { 開路 } \\
\text { 電圧 } \\
\text { (V) }\end{array}$} & \multicolumn{2}{|c|}{ 電 気 容 量 } \\
\hline & 陰極 & 電 & 解 & 液 & 陽 & 極 & & $\begin{array}{l}\text { Wh/cc } / \text { (theo) } \\
\text { (t) }\end{array}$ & $\begin{array}{c}\text { Wh/cc } \\
\text { (obs) }\end{array}$ \\
\hline 水銀電池 & $\mathrm{Zn}$ & \multicolumn{3}{|c|}{$\mathrm{NaOH}$ 又は $\mathrm{KOH}$} & $\mathrm{HgC}$ & & 1.35 & 2.4 & $0.30 \sim 0.55$ \\
\hline 酸化銀電池 & $\mathrm{Zn}$ & \multicolumn{3}{|c|}{$\mathrm{NaOH}$ 又は $\mathrm{KOH}$} & $\mathrm{Ag}_{2}$ & & 1.55 & 2.0 & $0.30 \sim 0.45$ \\
\hline 酸化銀 (II)電池 & $\mathrm{Zn}$ & \multicolumn{3}{|c|}{$\mathrm{NaOH}$ 又は $\mathrm{KOH}$} & $\mathrm{AgC}$ & & 1.55 & 3.1 & $0.40 \sim 0.60$ \\
\hline ニッケル亜鉛電池 & $\mathrm{Zn}$ & \multicolumn{3}{|c|}{$\mathrm{KOH}$} & $\mathrm{NiO}$ & & 1.60 & 1.6 & $0.15 \sim 0.20$ \\
\hline 空気覀鉛電池 & $\mathrm{Zn}$ & \multicolumn{3}{|c|}{$\mathrm{KOH}$} & air & & 1.50 & 5.4 & $0.9 \sim 1.0$ \\
\hline リチウム(松下)電池 & $\mathrm{Li}$ & \multicolumn{3}{|l|}{$r$} & (CF & & 2.8 & 2.0 & $0.40 \sim 0.60$ \\
\hline リチウム $(\mathrm{SAFT})$ 電池 & $\mathrm{Li}$ & \multicolumn{3}{|c|}{$\mathrm{PC}, \mathrm{LiClO}_{4}$} & $\mathrm{Ag}_{2}$ & & 3.4 & & 0.7 \\
\hline
\end{tabular}

性ソーダ $(\mathrm{NaOH})$, 苛性カリ $(\mathrm{KOH})$ 等のアルカリ水溶 液を用いたアルカリ電池は電圧変動が一般に小さく電子 腕時計等とくに精度を要求されるものに適している。 ま た，リチウム電池は内部抵抗が大きく，放電条件によっ て得られる容量が大きく異なってくる.

図 1 に放電電流を約 $0.2 \mathrm{~mA}$ とした場合の各種ボタン 型アルカリ電池の放電特性を, 図 2 に同じくリチウム電 池の放電特性を示す.

\section{2 温 度 特 性}

表 3 ボタン型電池の寸法, 種類と電気容量

枠内：左上 電池系 (陽極), 右上メーカ, 下 電気容量 $(\mathrm{mAh})$

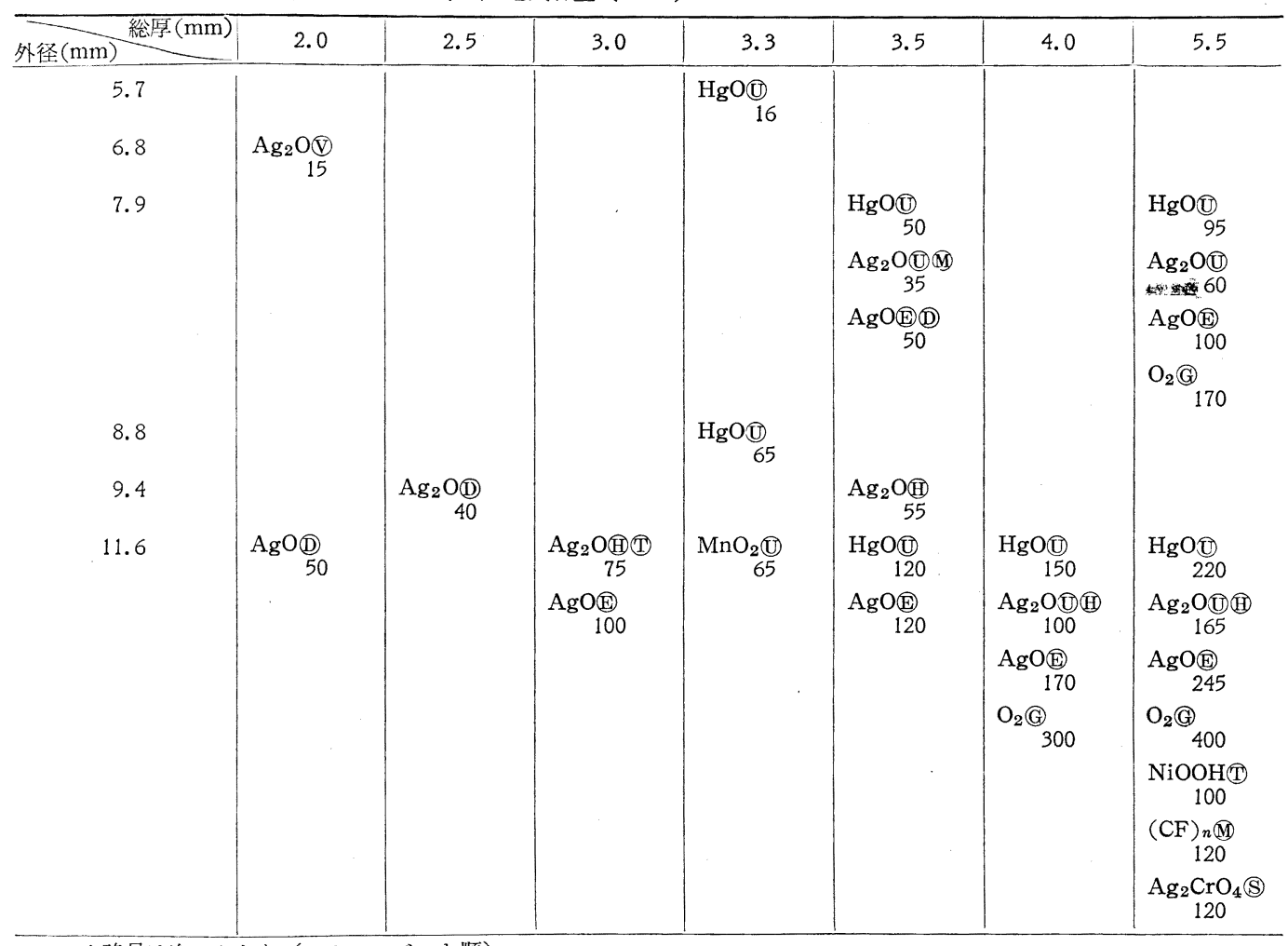

ーカ略号は次のとおり（アルファベット順）

(D): 第二精工含, (B): ESB(米国), (G)：Gould(米国)，(1)：日立マクセル，(M)：松下電器， (S)：SAFT(仏)，(1)：東芝又 は東芝レイオバック，(1)：UCC(米国)，(1)：VARTA(西独) 


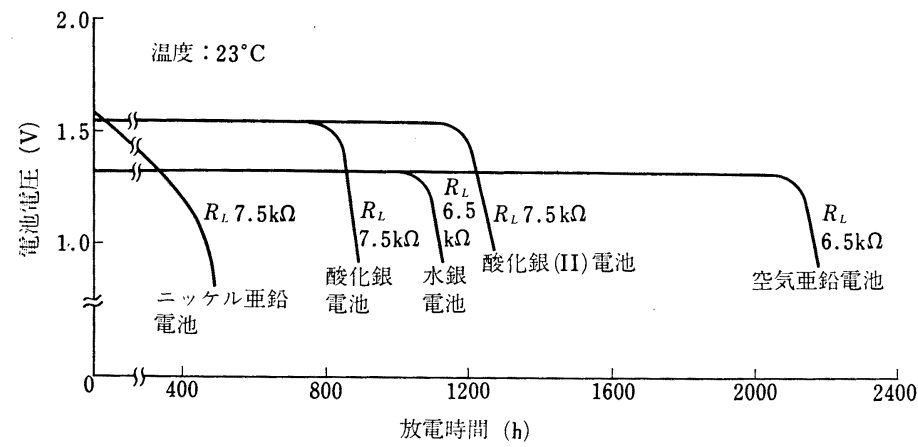

電池寸法： $\phi 11.6 \times 5.4 \mathrm{~mm}$

図 1 フルカリ電池の放電特性

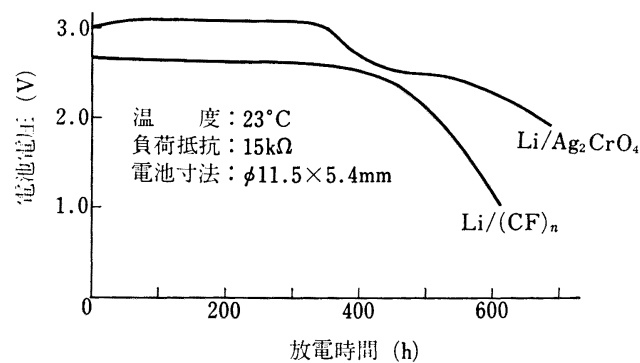

図 2 リチゥム電池の放電特性

電池の使用される環境は幅広いため温度特性も重要な 特性の一つである．低温から高温に至るまで安定して使 用できることが必要であるが，アルカリ電池は電解液と して $\mathrm{NaOH}$ あるいは $\mathrm{KOH}$ の水溶液が用いられるが，定 性的に示すと表 4 のごとく相違がある.

すなわち，微小電流で長期間にわたって使用する機器 に対しては $\mathrm{NaOH}$ 液が，大電流を必要とする機器には $\mathrm{KOH}$ 液を用いた電池が適している. 図 3 に酸化銀電池 における電解液の相違による内部抵抗の温度特性を示 す.リチウム電池は電解液にプロピレンカーボネート (PC) 等の有機溶媒を用いたものが小型化されているが, 低温に括いても性能劣化が少ない，図 4 にリチウム電池 の内部抵抗の温度特性を示す.

また，放電容量も温度により異なるが，リチウム電池 は低温においても容量の低下率が低く, アルカリ電池, 特に $\mathrm{NaOH}$ 液を用いたものは低温における容量低下が 大きい。図 5 に $23^{\circ} \mathrm{C}$ における容量を 100 とした場合の 各温度における容量比率を示す。

\section{3 保 存 寿 命}

電池活物質の電解液への溶解度, セパレータ材質（イ オンの透過度）等により保存寿命が決まるが, 電池寸法, 構造も重要な因子である，また，保管条件によっても大 きく左右され，高温に打いて一般に悪くなる．電池系に
表 4 電解液による特質

\begin{tabular}{c|c|c}
\hline 特 性 & $\mathrm{NaOH}$ 液 & $\mathrm{KOH}$ 液 \\
\hline 許容電流 & 小 & 大 \\
自己放電 & 小 & 大 \\
内部抵抗 & 大 & 小 \\
耐漏液性 & 大 & 小 \\
\hline
\end{tabular}

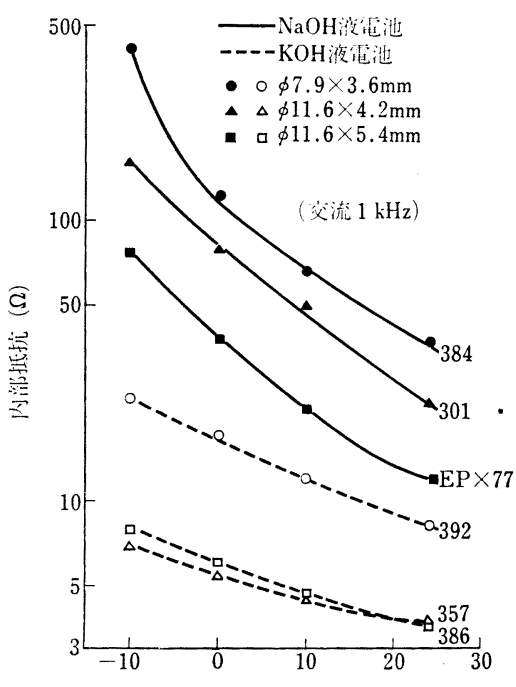

試料：UCC 社製電池

図 3 酸化銀電池の内部抵抗 - 温度特性

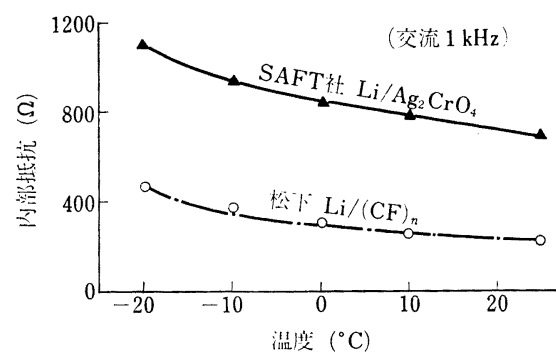

電池寸法： $\phi 11.6 \times 5.4 \mathrm{~mm}$

図 4 リチゥム電池の内部抵抗・温度特性

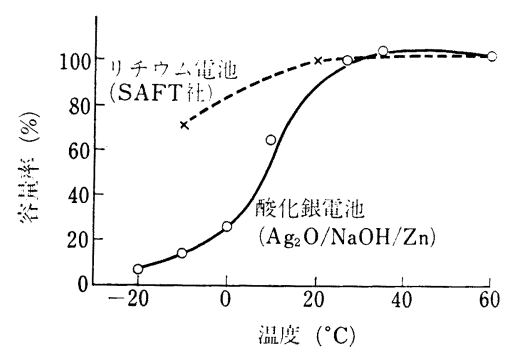

電池寸法： $\phi 11.6 \times 5.4 \mathrm{~mm}$

図 5 放電温度と容量 
表 5 保存条件による自己放電率の比較

（試料：UCC 社製 No. 392）

\begin{tabular}{c|c|c|c}
\hline 保 存 条 件 & $\begin{array}{c}\text { 初期容量 } \\
(\mathrm{mAh})\end{array}$ & $\begin{array}{c}\text { 保存後容量 } \\
(\mathrm{mA})\end{array}$ & $\begin{array}{c}\text { 己放電率 } \\
(\%)\end{array}$ \\
\hline$-10^{\circ} \mathrm{C}, 1$ 年間 & 38.0 & 35.2 & 7.4 \\
$23^{\circ} \mathrm{C}, 1$ 年間 & 38.0 & 29.2 & 23.2 \\
$60^{\circ} \mathrm{C}, 20$ 日間 & 38.0 & 29.4 & 22.6 \\
$60^{\circ} \mathrm{C}, 40$ 日間 & 38.0 & 24.6 & 35.3 \\
$70^{\circ} \mathrm{C}, 5$ 日間 & 38.0 & 28.8 & 24.2. \\
\hline
\end{tabular}

電池系: $\mathrm{Zn} / \mathrm{KOH} / \mathrm{Ag}_{2} \mathrm{O}$, 寸法: $\phi 7.9 \times 3.6 \mathrm{~mm}$

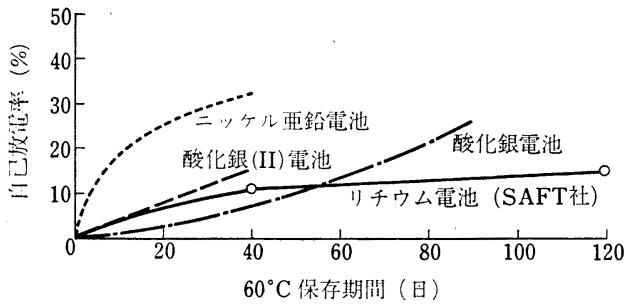

図 6 高温 $\left(60^{\circ} \mathrm{C}\right)$ 保存寿命の比較

よる相違が大きく、リチウム電池は優れた保存寿命を有 している. 表 5 に酸化銀電池を常温, 低温, 高温に保存 した場合の自己放電率の比較を示す. 高温における保存 寿命の劣化は大きく, $23^{\circ} \mathrm{C}, 1$ 年間の保存は, $60^{\circ} \mathrm{C}, 20$

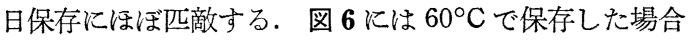
の各種電池の自己放電率の比較を示す.

なお，自己放電率とは次式で表されるものである.

自己放電率 $=($ 初期容量一保存後容量 $) /$ 初期容量

$$
\times 100(\%)
$$

\section{4 耐漏液性}

小型電池が当面している最大の問題と思われる. 小型 電池のほとんどが絶縁と封口を兼ねてナイロン等の合成 樹脂からなるガスケットを陰極缶と陽極缶の間に介在さ せているが，陰極缶とガスケットのすきまから電解液が はい上がり漏液となる. ハーメチックシール等による完 全密閉化は一つの解決手段と考学られるが，アルカリ電 池においては陰極に用いる亜鉛からのガス発生が避け難 く完全密閉化をより困難にしている．現在は液体パッキ ング材の使用等により漏液が発生するまでの期間を少し でも長くする努力がなされている.

\section{4. その他の小型電池}

小型化が進んでいる上述した 1 次電池のほかにボタン 型 2 次電池（蓄電池）あるいは細形シリンダ形状のリチ ウム電池がある. 現在のところ用途がまだ限定されてい るが，今後の電池として注目を要する. 細形リチウム電 池は松下電器より発売され, 電気うき用としてヒットし ているが, 今後他の機器への応用も十分に考觉られる. 表 6 にこれら小型電池の概要を示す.

\section{5. 小型電池の構造と製法}

ボタン型電池の構造は基本的にはほぼ同一であるが， 少しでも性能の高い電池をということで各電池メーカと も工夫しているところである.

図 7 (a)〜(d)にボタン型電池，図 7 (e) に細形リチウ 么電池の構造例を示す.

ボタン型電池の製法も各メーカでいかに安く高性能の 電池を造るかという観点から競争しているが，基本的に は次のような方法である.

陽極原料を混合，王粉成形し陽極缶内に充てんする. セパレータ, 電解液保持材等も陽極合剤上に載置し，ゲ ル状もしくは圧粉成形した亜鉛陰極を充てんした陰極缶 をガスケットを介して装入，かしめ加工により封口処理 される.このようにして製造された電池は数週間ないし 数か月間ェージングされ検査を経て出荷される.

小型電池の製造においては陽極，陰極活物質あるいは 電解液をいかに精度よく秤量装入するかがポイントであ る. また, 各部品の寸法精度も耐漏液性を始めとする諸 特性に大きく影響を及ぼすため高度の加工技術が要求さ れる。

製造環境も温度, 湿度, 不純物等について爰しくコン トロールしなければならない。

\section{6. 今 後の方 向}

電気エネルギを用いる機器数は今後共増大し，また携 帯に便利なようにより一層の小型化，軽量化が図られる であろう．電池の重要性がさらに増してくるであろう し，より敛しい注文が出されるであろう。

表 6 その他の小型電池

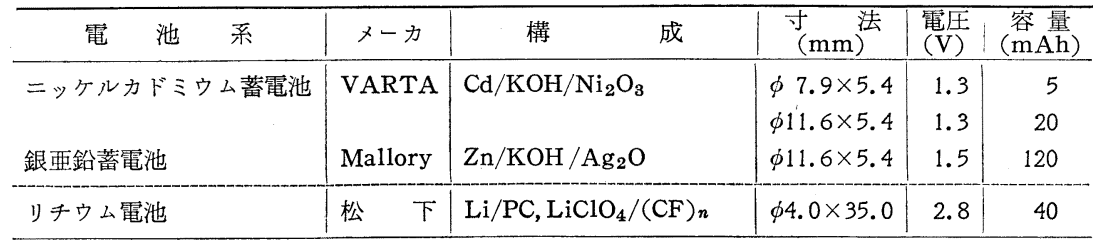




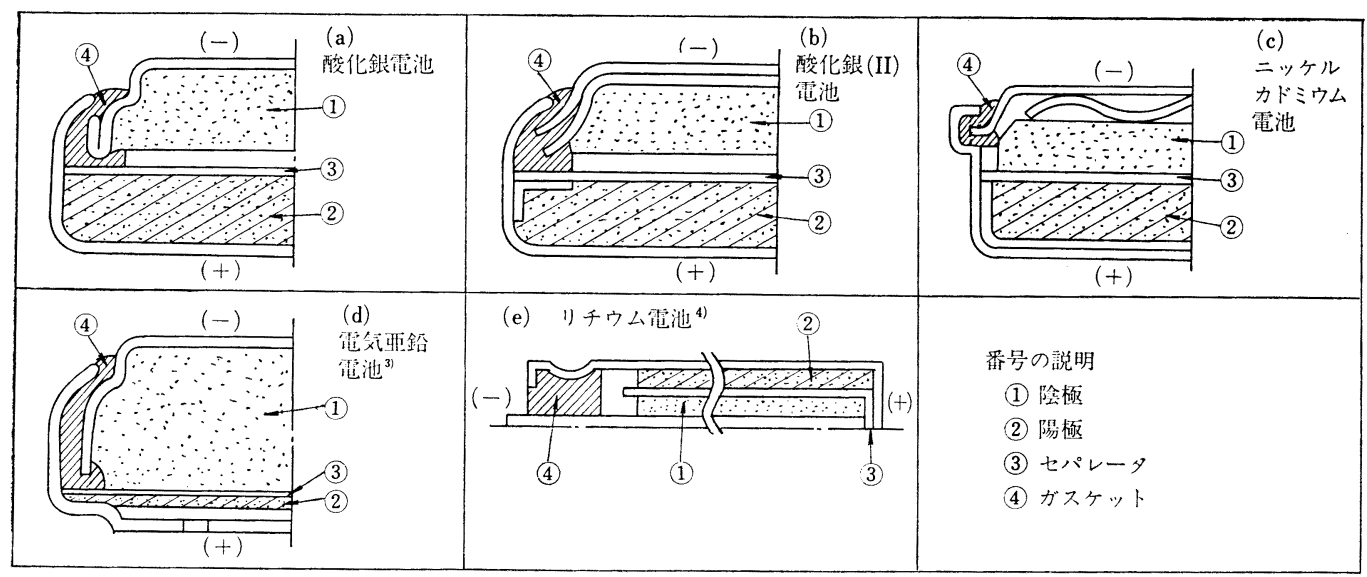

図 7 小型電池の構造例

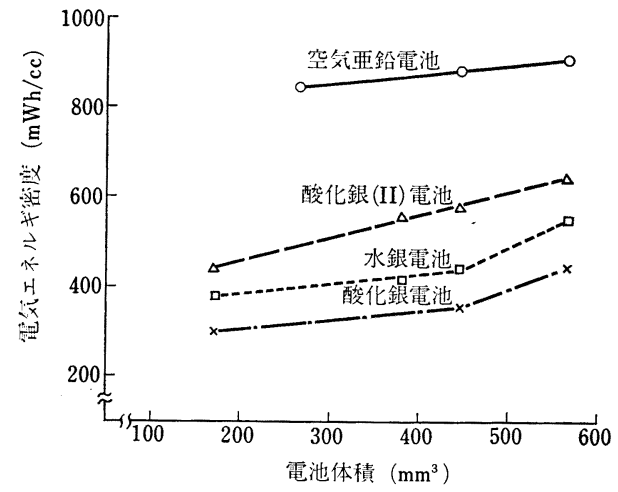

図 8 電池体積と電気エネルギ密度

現状においては，同一電池系においても小型化，薄型 化されるにしたがい,そのエネルギ密度が減少している. 図 8 に各電池系の体積とエネルギ密度の関係を示す．こ れは電池が小型化, 薄型化されても缶, セパレータ, ガ スケット等がさほど小型化されず相対的に占める率が高 くなるためである. 電池活物質の研究はよくされている が，缶，ガスケット等の研究はまだ十分とは言えず，今
後さらに小型, 薄型でエネルギ密度の婯い電池を開発す る上で, これらの研究開発が一つの鍵であろう.

また, 初期特性のほかに長期の信頼性がさらに重視さ れるであろう．消費電流の低減化に伴い電池寿命の長大 化が顕著であり長期安定性がより求められる. 現在, 実 用化の域にまだ到達しているとは見られなかったため, 本稿では省略したが，今後固体電解質電池も注目を集め よう.

今後共, 小型, 薄型で信頼性の高い電池は要望される であろうし，このような電池の出現を願ってやまない.

\section{参 考 文 献}

1）吉沢四郎監修：電池ハンドブック，電気書院 (1975) 1〜 49.

2) 高橋樟彦: 一次電池の発展に想 5 , 乾電池, 664 (1977) 8.

3) J. W. Cretzmeyer, H. R. Espig \& R. S. Melrose: Commercial Zinc-air Batteries, The 1976 Int. Power Sources Symp., (1976) 19.

4）福田雅太郎, 飯島孝志: 小型リチウム電池を量産, 電気 化学, 44, 8 (1976) 544 . 